\title{
ТРАНСКРИПЦИОННЫЕ ФАКТОРЫ NF-КВ И NRF2 КАК МИШЕНИ ФАРМАКОЛОГИЧЕСКОЙ КОРРЕКЦИИ ВОСПАЛИТЕЛЬНЫХ ПРОЦЕССОВ ПРЕПАРАТАМИ ГАМК ПРИ ЭКСПЕРИМЕНТАЛЬНОМ САХАРНОМ ДИАБЕТЕ
}

\author{
Ю.И. Великородная', А.В. Смирнов', И.Н. Тюренков ${ }^{2}$ \\ 1Лаборатория патоморфологии, ГБУ Волгоградский медицинский научный центр, \\ 400131, Россия, г. Волгоград, пл. Павших Борцов, 1. \\ ${ }^{2}$ Кафедра фармакологии и фармации НМФО, Волгоградский государственный \\ медицинский университет, 400131, Россия, г. Волгоград, пл. Павших Борцов, 1.
}

DOI: 10.19163/MedChemRussia2021-2021-492

E-mail:velikorodnaya@rihtop.ru

Несмотря на накопленный массив клинических и экспериментальных данных о патогенезе сахарного диабета (СД), далеко не все звенья молекулярных механизмов являются мишенью для фармакологической коррекции данного метаболического нарушения.

Устойчивое состояние гипергликемиисопряжено с повышением активности транскрипционного фактора NF-kappaB (NF-кB), который играет ведущую роль в развитии СД и связанных с ним осложнений. Длительная активация NF-кB вызывает системное воспаление, стимулируя продукцию провоспалительных цитокинов (IL-6, IL-1b, $\alpha$-TNF), а также участвует в развитии окислительного стресса [1].

В противоположность NF-кB, ядерный фактор транскрипции NRF2, индуцируемый в ответ на окислительный стресс, тормозит выработку провоспалительных цитокинов и при этом активирует ферменты антиоксидантной защиты и ферменты II фазы детоксикации, включая гемоксигеназу-1, хиноноксидоредуктазу и супероксиддисмутазу[2].

Гамма-аминомасляная кислота (ГАМК) - основной нейротрансмиттер, который продуцируется также и $\beta$-клетками. Противовоспалительное действие ГАМК опосредуется через экспрессию белка Клото, механизм действия которого направлен на ингибирование NF-кB с одновременной индукцией сигнальных путей SIRT-1, PI3K-Akt и CREB-IRS-2, отвечающих за регенерацию и дифференцировку клеток [3].

Таким образом, применение ГАМК в качестве активатора NRF2 и/или ингибитора NF-кB может оказаться перспективной стратегией фармакологической коррекции воспаления и осложнений, вызванных сахарным диабетом.

\section{Литература}

[1] S.V. Suryavanshand Y.A. Kulkarni, Frontiers in Pharmacology ,2017, 8, 798.

[2] H.E. de Vries, M. Witte, D. Hondius, A.J. Rozemuller, B. Drukarch, J. Hoozemans and

J. van Horssen, Free Radical Biology and Medicine, 2008, 45, 1375-83.

[3] А.А. Нестерова, Е.Ю. Глинка, И.Н. Тюренков, и В.Н Перфилова, Успехи физиологических наук, 2020, 51, 88-104. 